\title{
Unilateral iatrogenic ptosis
}

\author{
Ali S Hassan, Huw Oliphant, Paul Baddeley
}

Department of Ophthalmology, Worthing Hospital, Worthing, West Sussex, UK

\section{Correspondence to}

Dr Ali S Hassan, alishassan@doctors.org.uk

\section{CrossMark}

\author{
To cite: Hassan AS, \\ Oliphant H, Baddeley P. BMJ \\ Case Rep Published online: \\ [please include Day Month \\ Year] doi:10.1136/bcr-2013- \\ 201867
}

\section{DESCRIPTION}

A 60-year-old man presented with a 2-year history of gradually worsening ptosis affecting his left upper lid. Nine years ago he had undergone excision of a left acoustic neuroma; this resulted in a left-sided facial palsy, which was partially treated with a facial nerve graft. Despite this, his left eyelid closure remained poor and within 1 year he developed exposure keratopathy. An upper lid gold weight implant was then inserted to improve the lid closure.

At presentation, the eye examination revealed a $3.5 \mathrm{~mm}$ left-sided ptosis, pupils were equal and reactive to light and the ocular motility was normal. Bilaterally upper lid dermatochalasis was noted, additionally, a firm $6 \mathrm{~mm} \times 20 \mathrm{~mm}$ protuberant mass was noted beneath the skin overlying the left upper lid (figure 1).

Blinking and eyelid closure is a function of the orbicularis oculi which is innervated by the temporal and zygomatic branches of the facial nerve. Facial nerve palsies can denervate the orbicularis oculi resulting in lagophthalmos (incomplete lid

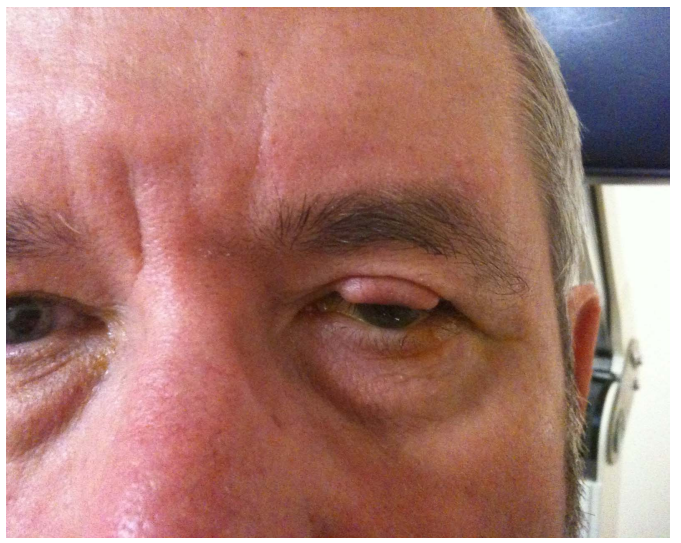

Figure 1 A firm $6 \mathrm{~mm} \times 20 \mathrm{~mm}$ protruding mass was noted beneath the skin overlying the left upper lid causing a $3.5 \mathrm{~mm}$ ptosis. closure). ${ }^{1}$ Facial nerve grafts can re-innervate the muscles of the face, although this is often with only partial success. ${ }^{2}$ Upper eyelid gold weight implantation is one method of improving the lid closure by loading the upper lid with additional weight. ${ }^{3}$ However, gold weight implant migration can occur resulting in iatrogenic ptosis. ${ }^{4}$ The management involves removal of the gold weight and reinsertion at a later date if exposure keratopathy recurs.

\section{Learning points}

- De-innervation of the orbicularis oculi muscle causes incomplete blinking and lid closure (lagophthalmos) which can damage the cornea and affect the sight.

- In patients who present with facial nerve palsy, consideration must be given to the cornea. Regular ocular surface lubrication and nighttime eyelid taping is required.

- The definitive management of lagophthalmos can include gold weight insertion into the upper eyelid to improve the lid closure; however, this can lead to iatrogenic ptosis.

Competing interests None.

Patient consent Obtained.

Provenance and peer review Not commissioned; externally peer reviewed.

\section{REFERENCES}

1 Kim C, Lelli GJ Jr. Current considerations in the management of facial nerve palsy. Curr Opin Ophthalmol 2013;24:478-83.

2 Volk GF, Pantel M, Guntinas-Lichius O. Modern concepts in facial nerve reconstruction. Head Face Med 2010;6:25

3 Baheerathan N, Ethunandan M, Ilankovan V. Gold weight implants in the management of paralytic lagophthalmos. Int J Oral Maxillofac Surg 2009;38:632-6.

4 Harrisberg BP, Singh RP, Croxson GR, et al. Long-term outcome of gold eyelid weights in patients with facial nerve palsy. Otol Neurotol 2001;22:397-400.

\footnotetext{
Copyright 2014 BMJ Publishing Group. All rights reserved. For permission to reuse any of this content visit http://group.bmj.com/group/rights-licensing/permissions.

BMJ Case Report Fellows may re-use this article for personal use and teaching without any further permission.

Become a Fellow of BMJ Case Reports today and you can:

- Submit as many cases as you like

- Enjoy fast sympathetic peer review and rapid publication of accepted articles

- Access all the published articles

- Re-use any of the published material for personal use and teaching without further permission

For information on Institutional Fellowships contact consortiasales@bmjgroup.com

Visit casereports.bmj.com for more articles like this and to become a Fellow
} 